\title{
所謂炭坑夫塵肺症に認められた潜在性 微小肺㓔痕癌について
}

\author{
Latent Scar Cancer of the Lung in Coal-Worker's Pneumoconiosis \\ 田原栄一* · 山田 明* ・ 井原俊彦* ・西田修実**
}

\begin{abstract}
抄録：14年間の職業歴を有する46才男性の炭坑夫塵肺症の一剖検例に認められた所謂潜在性微小 肺瘢痕癌について，その組織発生に核心をおいて報告した．左肺上葉助膜下の珪酸炭粉結 節を有する瘢痕組織を場として発生した腺癌であって転移はない。その瘷痕内〜周囲には 多彩な病変が混在し, その癌腫と細気管支上皮及び腺様増殖との連続性を明らかに認めた。 職業性肺癌とはいえ，末梢性痏痕癌の組織発生に種々なる示唆を与えた症例である.
\end{abstract}

古くは，Schneeberg扩よびJoachimstal 鉱山に於 いて肺癌の多発が問題にされて以来，珪肺症などと 肺癌との病因論的関係については，今日な㧍替否両 論がある.また, Rössle ${ }^{1)}$ および Friedlich ${ }^{2)}$ の報告 を唂矢とする肺の痏痕癌については，その判定規準， 瘢痕の性状および成因，さらにはその組織発生など に於て諸家により著しく差があり, 就中塵肺性㓔痕 癌が占める比率も一定していない。

著者らは, いわゆる炭坑夫塵肺症に於て珪肺炭粉 結節を場として発生した潜在性㾉痕癌を経験したの で，その概要に疫痕癌の組織発生について若干の考 察を加えて報告することとする。

\section{症 例}

46才, 男性

\section{I. 臨床的事項}

主 訴: 呼吸困難, 咳嗽

職業歴：昭和 22 年ょり 14 年間, 炭坑堀進夫として 就労.

家族歴および既往歴：特記すべきものはない。

現病歴：昭和 22 年より 37 年まで炭坑の堀進夫とし て働いていたところ, 昭和35年頃より坂道を登る時, 息切れが生じ, さらに咳嗽, 全身倦急感が加って来

*広島大学医学部 病理学教室

(指導：山田 明教授)

** 広島大学医学部 第 2 内科学教室

(指導：西本幸男教授)
たが，放置していた。昭和36年の末期からるいそう が目立つようになり，微熱も発生して来たので昭和 37 年 1 月退社した。同年末頃より膿性喀痰か加わり, 昭和 38 年 4 月塺肺結核症と診断され, 某病院に入院 し，翌年の 2 月まで， SM，PAS，INAHなどの投 与を受け治療つづけていたが, ばち状指の出現が見 られるようになった。质の後自宅療養していたが, 昭和 40 年 5 月本学第 2 内科に入院した.

経 過：入院後, 呼吸困難, 咳嗽ならびに膿性喀 痰などが増悪し，同年 7 年頃より胸痛，頭痛，血痰 なども出現し, 昭和 42 年 6 月 14 日急性肺炎にて死亡 した。

昭和 42 年 4 月の諸種検查成績は次の如くである. 一般検查成績: 赤血球数 427 万, $\mathrm{Hb}$ (Sahli) $100 \%$, $\mathrm{H} \mathrm{t} 52 \%$, 白血球数 10,600 (分類では好酸球増多 (9 $\%$ ）がみられる他異常はない). 赤沈 1 時間值 $35 \mathrm{~mm}$. 尿に異常所見なし，喀痰の叙抹・培養検査では結核 菌は陰性であり, 細胞診では 6 回とも悪性細胞は検 出されなかった(Class 1). 肝機能検査では血清総蛋 白 $7.2 \mathrm{~g} / \mathrm{dl}, \mathrm{A} / \mathrm{G} 0.52$, 総ビリルビン $0.8 \mathrm{mg} / \mathrm{dl}, \mathrm{Zn}$

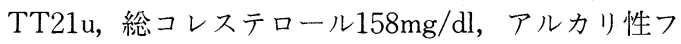
オスファターゼ14u, GOT16u, GPT11uで, ZnTT が増加し, 血清総蛋白では $\mathrm{Al} 41.3 \%, \alpha_{1}$-Gl 2.3\%, $\alpha_{2}$-Gl 8.1\%, $\beta$-Gl 8.7\%, $\gamma$-Gl 39.6\%で, $\mathrm{Al}$ の減少 と $\gamma$-Glの増加がみられる。. その他 $\mathrm{CRP}(-), \mathrm{RA}(+)$, 梅毒反応 $(-)$, ッベルクリン反応 $(+)$ ，である。 ま た心電困に異常はみられない。

肺機能検查成績: 肺活量2.52l (66\%), 全肺気量 
4.431 , 生理的死腔量 $336 \mathrm{ml}, 1$ 回換気量 $600 \mathrm{ml}$, 呼吸 数 $26 / \mathrm{min}$, 分時換気量 $15.6 \mathrm{l} / \mathrm{min}$, 肺胞換気量 $4.9 \mathrm{l} /$ $\mathrm{min}, 1$ 秒率 $36 \%$, 最大換気量 $106.81 / \mathrm{min}(87 \%)$, 気 道抵抗 $3.5 \mathrm{~cm} \mathrm{H}_{2} \mathrm{O} / \mathrm{l} / \mathrm{sec}$, 静肺コンプライアンス 0.045 $\mathrm{l} / \mathrm{cm} \mathrm{H}_{2} \mathrm{O}$, 肺胞気一動脈血間 $\mathrm{O}_{2}$ 分圧較差 $49.0 \mathrm{mmHg}$, 動脈血一肺胞気 $\mathrm{CO}_{2}$ 分圧較差 $10.1 \mathrm{mmHg}, \mathrm{CO}$ 肺拡散 能力 $12.8 \mathrm{ml} / \mathrm{min} / \mathrm{mmHg}(42 \%)$, 膜拡散能力 $17.4 \mathrm{ml} /$ $\mathrm{min} / \mathrm{mmHg}$, 肺毛細管血量 $47.0 \mathrm{ml}$, 動脈血 $\mathrm{O}_{2}$ 分圧 53.0 $\mathrm{mmHg}, \mathrm{CO}_{2}$ 分圧 $38.5 \mathrm{mmHg}, \mathrm{pH} 7,463, \mathrm{O}_{2}$ 飽和度 $87.5 \%$ で，換気機能はほとんど正常であるが，肺コ ンプライアンスが著明に低下し，さらに肺拡散能力 （とくに膜拡散能力）が著減している. 肺胞過換気 により呼吸性アルカローシスになっているが，動脈 血 $\mathrm{O}_{2}$ 分圧および飽和度は拡散障害により著明に低下 している.

胸部 X線所見：両側肺尖部を除いた全肺野に大小 不同の粒状㓌影がびまん性に散布しており，上・中 肺野外側にはこれらの小融合像が散見され，わが国 の塵肺法によるX線分類にしたがうと $\mathrm{PR}_{4} \mathrm{~A}$ に相当 する所見を呈している．また両側下肺野とくに横隔 膜上部には中等度の網状影の散布がみられ，この部 分の強い線維性変化がうかがえる. なお心院影に異 常なく, 肺門部に卵殼㓌影は認められない(写真 1 ).

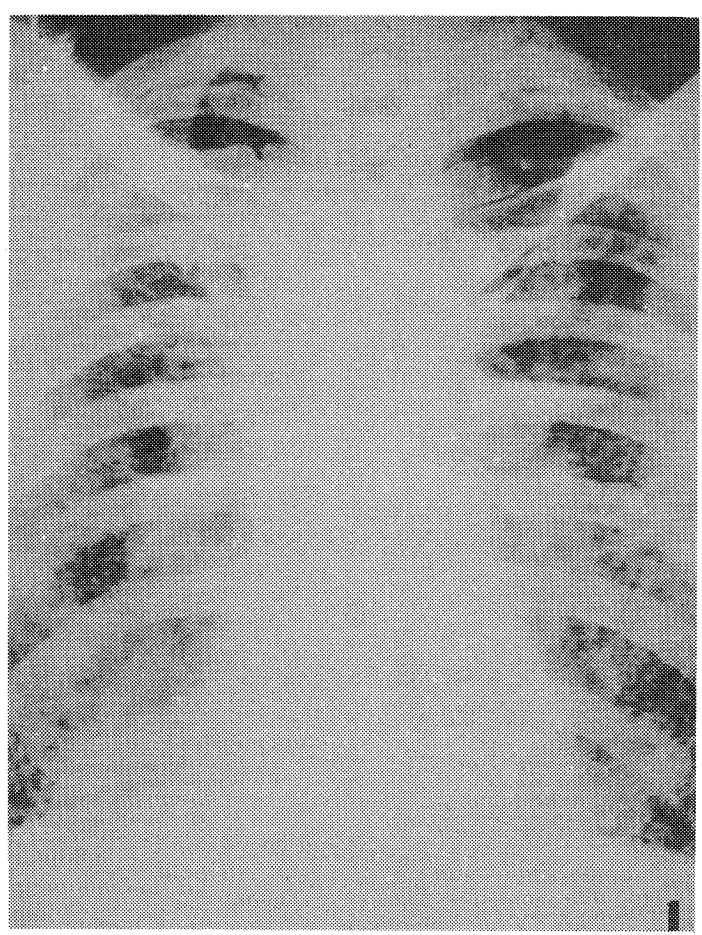

写真 1 胸部 X線フィルム (昭和 42 年 4 月撮影)

\section{II. 病理学的事項}

1) 主要病理解剖学的所見

死後 2 時間にて解屍され，身長 $170 \mathrm{~cm}$, 体重 $47 \mathrm{~kg}$, るいそうが著明である，腹腔内には著変はないが, 左胸水 (半透明性) $150 \mathrm{cc}$ を認める. 肋膜の線維性癒 着を両上葉の一部に認める.

肺 臓：重量右 $1,100 \mathrm{~g}$, 左 $960 \mathrm{~g}(10 \%$ ホルマリン 1 もを気管より注入後の測定值). 両肺ともに, 黒色粉 塵沈着が全般的に著しく, かつ, 線維性肋膜の肥厚 を伴なっている．割面では，両肺の全葉にわたって， 瀰漫性の線維症が存在し, 両上葉に於ては, 拇指等 大一小指等大の炭粉結節が多数散在し, 同時に, 肺 気腫および気管支拡張症を合併し, さらに下葉に於 てはそれら拡大した肺胞あるいは細気管支腔に膿様 滲出物が充満して, いわゆる蜂巣状肺の外観を呈し ている. 両肺門リンパ節はいずれも黒色粉塵沈着が 極めて顕著で, 胡桃大〜拇指等大に腫大し, 硬い線 維性結節が散在に認められる(写真 2,3 ).

組織学的には，両上葉の炭粉結節は黒色粉塵によ ってとり囲まれた硝子様結合織から成るほぼ定型的 な珪酸炭粉結節であって (写真 4$)$. 偏光顕微鏡下で は，多数の鉱物質が存在している，瘢痕内および周 囲には，細気管支ないしは肺胞上皮の腺様増殖が著 しく認められ，部位によっては，それらの扁平上皮 化生あるいは異型的上皮の増殖が見出される。そし て左上葉 $\left(S_{1+2}\right)$ に於ける肋膜直下に存在する痗痕組 織内およびその周辺には, 図 1 の如く腺様増殖と乳 頭腺管腺癌とが相接して存在しているのが認められ る.また他の部では, 間質の線維化, あるいは線維 化による肺胞壁の破壊の結果, 拡大した distal air spase を示す蜂巣状の構造を示し, その壁には, 立 方状ないしは骰子状上皮ならびに重層扁平上皮が配 列し, 多くは好中球の滲出を含有している。一方, 両肺の線維化の比較的軽度の部に於いては, 肺気腫 と共に, 細気管支と肺胞との直接的な交通すなわち Lambert ${ }^{3)}$ (1955)のいう “accessory bronchiale-alveolar communication”が散在性に見出され，その小管 には塵肺食細胞の蓄積が屢々認められるのである(写 真 5). また，一般的に，気管支から細気管支にかけ て,その壁および周囲の線維化, 慢性炎症性細胞の浸 潤が著しく，上皮成分には，扁平上皮化生，杯細胞 の増殖，繊毛上皮細胞の萎縮ならびに腺様増殖など と多彩な病変が混在している。なお, 左上葉に於け る瘢痕内に発生した腺癌は，気管支および肺門りン パ節を含めて他の臓器への転移形成は認めていない. その他の諸蔵器の主病変および主要剖検診断は次の 如くである. 


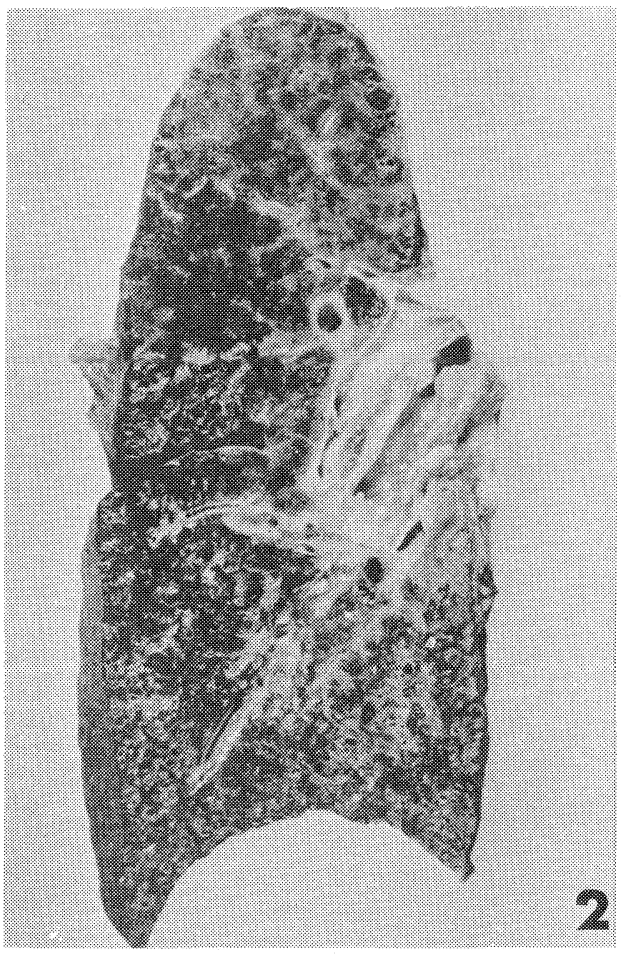

写真 2 左肺肉眼像

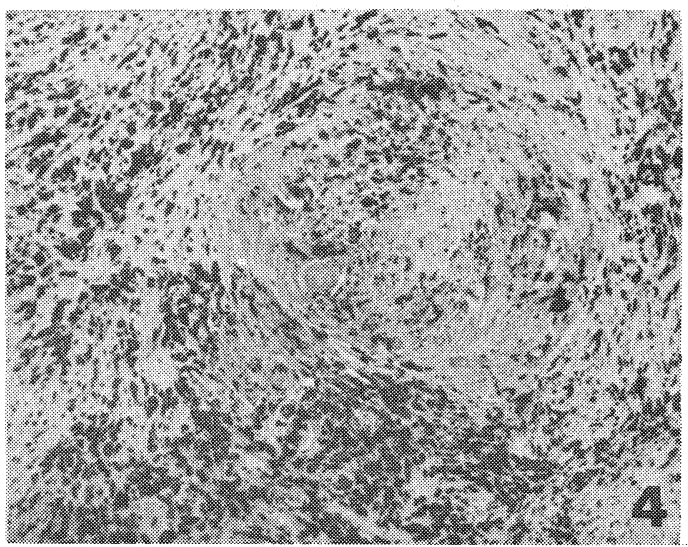

写真 4 左肺上葉の珪酸炭粉結節

\section{2）主要剖検診断}

1. 気管支癌 (腺癌)，左上葉，珪酸炭粉結節を場 として発生したいわゆる痗痕癌.

2. 珪酸炭粉結節の形成を伴う炭坑夫塵肺症.

1) 両肺門リンパ節の線維症. 2）肺気腫. 3）気 管支拡張症４４）慢性気管支一細気管支炎.

3. 化膿性気管支肺炎, 両側.

4. 滲出性肋膜炎 (胸水 $150 \mathrm{cc}$ ), 左側.

5. 慢性消化性胃潰瘍, 胃角部小彎側.

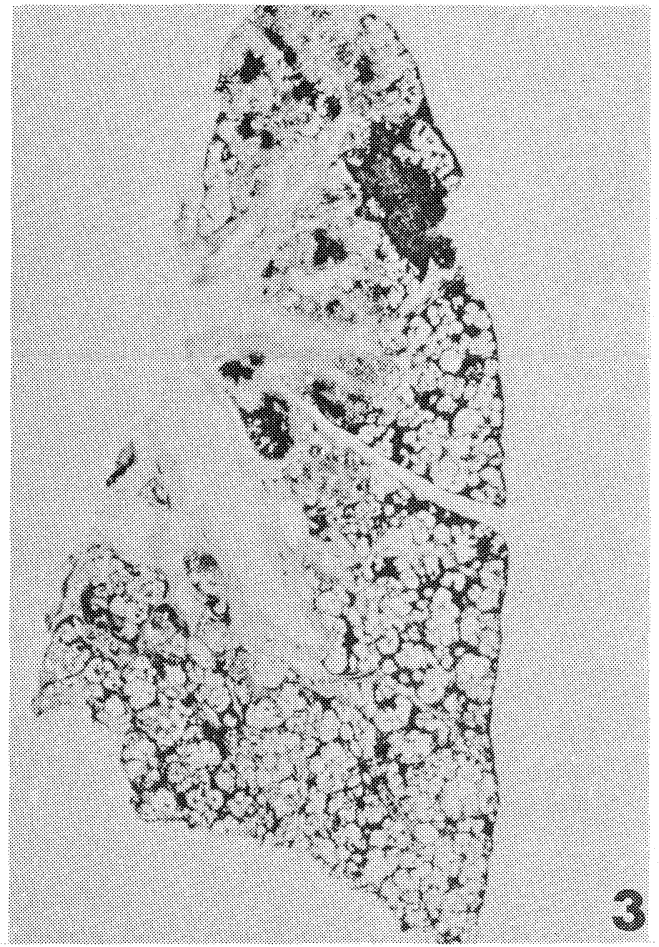

写真 3 右肺大切片標本

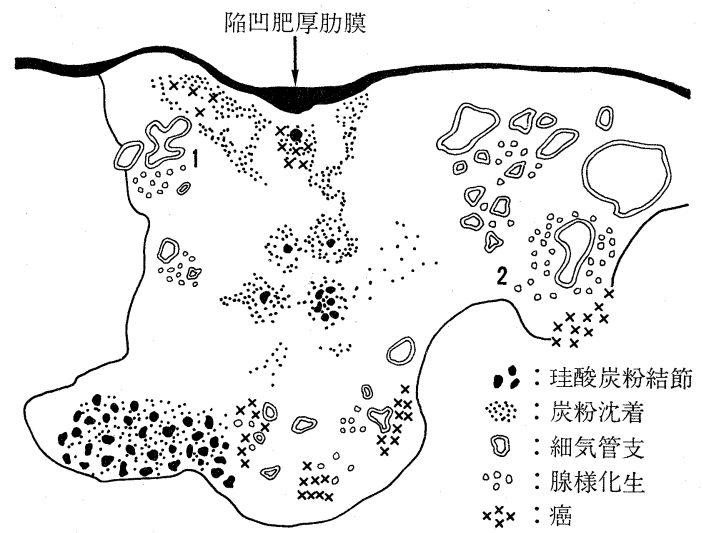

困 1 左上葉の瘢痕組織内における諸病変の分布

6. 全身性動脈硬化症.

3）左肺上葉に於ける疫痕癌について

左上葉の珪酸炭粉結節に発生したいわゆる瘏痕癌 の組織発生を追求する目的で，図 1 のシェーマにす でに示した 1 および 2 の部に於ける細気管支上皮な いしは肺胞上皮の腺様増殖と腺癌との関係を連続切 片にて検索してみた。すなおち 1 の部では, 腺様増 殖と腺癌とが相接して存在している. 今, 異型性の 目立たない骰子状上皮を有し，内腔にはcoal dustの 
356

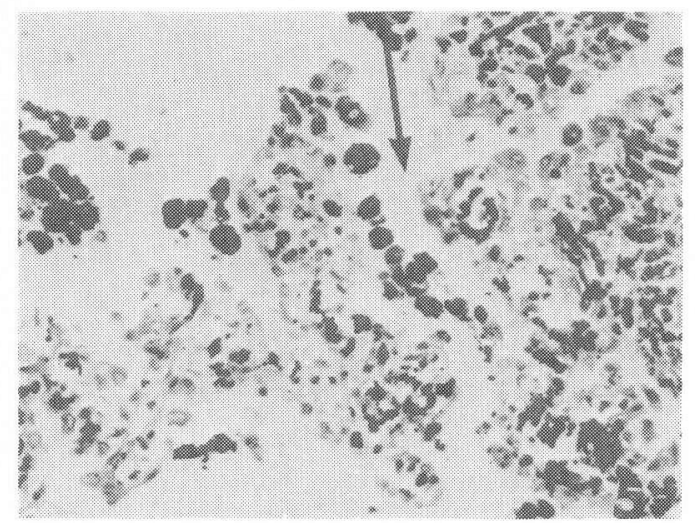

写真 5 いわゆるLambertのcanal (七) に於ける塵 肺食細胞の蓄積

停滞を示す腺様増殖の部を連続切片にて追ってみる と(写真 $6 \mathrm{~A})$, 上皮細胞が丈が大となりないしは立方 状となり，また異型性が強くなり，一部では乳頭状 の増殖がみられ(写真 $6 \mathrm{~B})$. さらにそれらが一層顕著 となって乳頭一腺管腺癌と見做されるようになる(宁 真 $6 C)$. そしてさらに浸潤性増殖像の強い腺癌となる (写真 6D). 次に2 の部に見られる拡大した細気管支 をねらって再び連続切片にて追求してみると, 先ず 相交通する拡大した細気管支とその周囲に腺癌が存
所謂炭坑夫塺肺症に認められた潜在性微小肺瘷痕癌について 在するが(䒓真 7A). その拡大した細気管支の粘膜上 皮の一部に異型増殖が見出されるようになり（写真 7B), さらにそれらは異型的な乳頭上皮の増殖を示し， 腺癌と考之られる(写真 $7 C)$ 。 そして周囲の浸潤性増 殖を示す癌腫と連続することとなる(写真 7D).

\section{考 按}

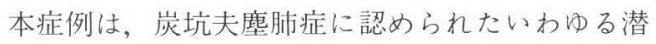
在性微小痗痕癌と見做され, 癌腫に先行する珪酸炭 粉結節を示す瘢痕，その瘷痕組織周辺に於ける多彩 なる組織像を示す上皮細胞の非癌性增殖と腺癌組織 との共在ならびに癌組織と細気管支上皮あるいは腺 様増殖との連続性が確認されたことなどよりして, 影山, ${ }^{4)}$ (5) 北川 ${ }^{6)}$ らの疲痕癌の厳重なる規準に立分満足 し得るものと考えられる.

さて, 塵肺性疫痕の肺癌発生母地的意義について は，な扔意見の一致を見ていないが，Hueper ${ }^{7)} に よ$ ると, 瘢痕組織周辺の癌発生は, 炭粉あるいは珪酸 塩そのものの長期にわたる慢性刺激，あるいは気管 支上皮細胞の再生性増殖の歪みの結果ではなくして， 瘢痕組織がその環境的立場から発癌の予備的な場と して存在し、それに 2 次的な発癌物質の曝露が加わ って発癌して来るものと推論している. そして,
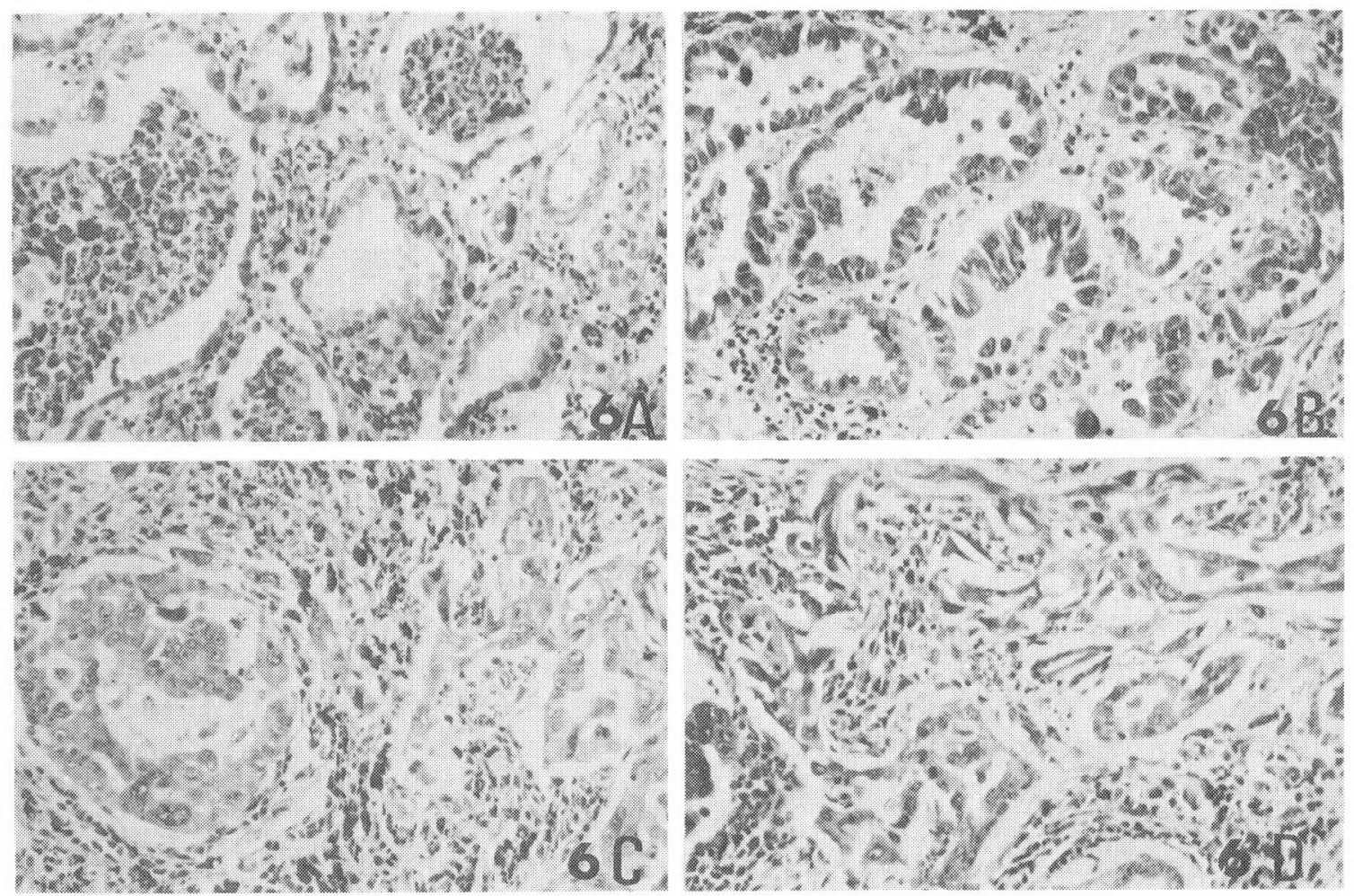

写真 6 表の 1 の腺様増殖 $(6 \mathrm{~A})$ から異型的増殖 $(6 \mathrm{~B})$, さらに腺癌 $(6 \mathrm{C}, \mathrm{D})$ 一の連続性 

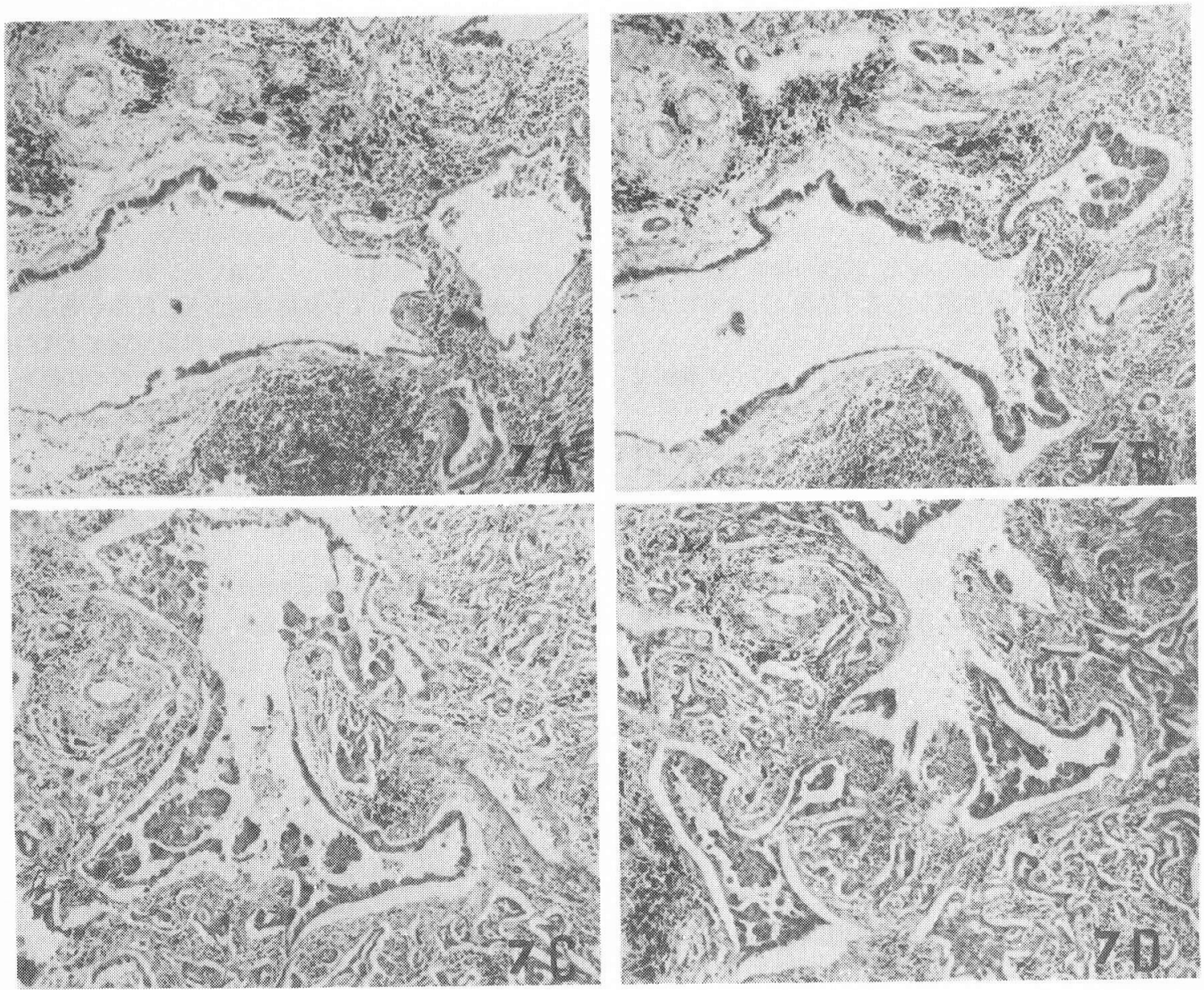

写真 7 表の 2 の部の細気管枝 $(7 \mathrm{~A})$ から腺癌 $(7 \mathrm{C}, \mathrm{D})$ への連続性

Mittmann, Kahlau ${ }^{9)}$ らは, 珪肺症ないしは肺線維化 の程度と肺癌発生との関係を強調している。すなわ ち，軽度の珪肺症の方が，中等度ないしは高度の珪 肺症に比べて，肺癌が圧倒的に頻発している事実か ら，広汎なる線維化あるいは硝子化の陳旧性病変よ ク，初期の線維化ないしは珪肺症の方が肺癌の発生 と発育に適したよき場となり得るであるうと述べて いる，彼らのこのような考え方は，その正否は別と して，痗痕癌の組織発生に於ける一般的問題点の一 つとして考慮に価するものと思われる。

次に，本例に認められた腺様増殖，異型的増殖な らびに腺癌との因果関係については, 連続切片の追 求により，それらはお互に連続性が明らかに確認さ れたことから，次の3 点が考えられる.すなわち， 少なくとも，二つの異なった因子がそれぞれ腺様増 殖に働いて異型的増殖と癌とが別々に発生せしめた のか，あるいは同じ因子によって異型的増殖と癌と が同時に腺様増殖から発生して来たのか, さらには

一つの因子によって形成された異型的増殖に他の因 子の相乗作用が加わって癌が発生したものなどが想 定される。いずれにしろ両肺に散在する疫痕と腺様 增殖の位置的分布からして，何らかの因子により， 腺様増殖を母地として多中心性に発生した末梢性㓔 痕癌と見做してもさしたる異論はないと考えられる のである。

かかる㓔痕癌の組織発生の上皮由来については, 従来上り末梢気管支上皮由来説と肺胞上皮由来説と があり論議のあることは周知のところである。本症 例に於ては，細気管支上皮と癌腫との連続性が確か められたこと，またMeyerら ${ }^{10)} の$ 報告の如く、いわ

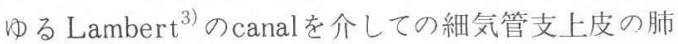
胞への直接的な異型的增殖の進展とその異型的増殖 と癌腫との共存等から, 本例の腺癌発生は細気管支 上皮由来と考える方が最も妥当かと思われる。しか しながら、このような所見といえども肺胞上皮から の発生を完全に否定する根拠とはなりえないと考え 
られる。なぜならば，腺様増殖にも，癌の場合と同 様に，細気管支上皮由来と肺胞上皮殊にB 型の肺胞 上皮由来とがあると考えられ，後者からの腺様增殖 さらに発癌という過程は否定し得ないからである。 事実，著者ら ${ }^{11)} の \mathrm{X}$ 線外部照射によるマウス肺腫瘍 の実験研究に於いては，B型の肺胞上皮からの腺腫 および腺様增殖を電顕的観察しており，またさらに 肺の発生学的立場から見て，B 型の肺胞上皮からの 腫瘍発生があっても決して不可思議ではないのであ る.

従って，瘢痕癌の組織発生には，マウスの腫瘍発 生の場合と同様に肺胞上皮由来のものがあるかどう かは, 一般的な肺癌の発生の問題とからんで, 今後 解明されなければならない点と考えられる。

一方，近年肺癌の増加に伴い大気污染，喫煙など が注目されており，症痕癌の成因として結核性のみ ならず大気污染及び喫煙の面をも重視すべきである ことを併せ考えると, 本症例が炭坑夫に発生した職
業性肺癌とはいえ，末梢性㓔痕癌の組織発生に種々 なる興味ある示唆を与える興味ある症例と考えられ る.

\section{結 語}

14年間の職業歴を有する46才の男性の炭坑夫塵肺 症に認れた潜在性微小躿痕癌について報告し, ことにその組織発生について論じた. 瘢痕癌の癌組 織と細気管上皮および腺様増殖との連続性を明らか に認めたことから，その組織発生は細気管支上皮由 来と説明し得るが, 腺様増殖の発生母細胞の問題を も含めて肺胞上皮由来をも考慮されなければならな いと考えられる.

欄筆に当り，御校閲を賜った西本幸男教授に謝意を表 します。

なお本論文の要旨は日本肺癌学会中国四国地方会第 7 回総会（昭和43年）に於いて発表した.

\title{
文 献
}

1) Rössle, R. : Schweiz. Med. Wchnschr., 73:1200, 1943.

2) Friedlich, G.: Virchows Arch. Path. Anat., 70: $230,1939$.

3) Lambert M. W. : Journal of Path. Bact., 70: $311,1955$.

4 ）影山圭三: 癌の臨床, 9:132, 1963.

5 ）影山圭三：日本臨床, $24: 395,1966$.

6) 北川正信：Acta Path. Jap., 15:199, 1965.

7 ) Hueper, W. C. : Recent Results in Cancer

Research. Springer-Verlag Berlin Heidelberg, New York, 1966.

8 ) Mittmann, O.: Forschungs-Arbeiten aus dem wissenschaftlich-statistischen. Sektor der Krebsforschung NW. Bonn., 1959.

9 ) Kahlau, G. : Ergebn. allg. Path. Anat., 37:258, 1954.

10) Meyer, E. C. et al. : Cancer, 18:322, 1965.

11) 田原栄一ら：肺癌, $11: 181,1971$.

Latent Scar Cancer of the Lung

in Coal-Worker's Pneumoconiosis

\author{
E. Tahara*, A. Yamada*, T. Ihara* and S. Nishida** \\ Department of Pathology* ( Director, Prof. A. Yamada ) and \\ Medicine** ( Director, Prof. Y. Nishimoto ), \\ Hiroshima University School of Medicine.
}

An autopsy case of small scar cancer of the lung in a 46-years old man sufferring from coal-worker's pneumoconiosis was presented and described the histogenesis of this tumor. 
Present study was apparently exhibited the transition of normal bronchiolar epithelium or adenomatous hyperplasia of bronchiolar and alveolar cells to adenocarcinoma arising in subpleural scar tissue. Scar carcinoma of the lung may possibly not be of bronchiolar origine but also of alveolar cell origine as well as adenomatous hyperplasia. 